\title{
Modularity and Morality in the Law of Torts
}

\section{Citation}

Henry E. Smith, Modularity and Morality in the Law of Torts, 4 Journal of Tort Law (2011).

\section{Permanent link}

http://nrs.harvard.edu/urn-3:HUL.InstRepos:8789603

\section{Terms of Use}

This article was downloaded from Harvard University's DASH repository, and is made available under the terms and conditions applicable to Open Access Policy Articles, as set forth at http:// nrs.harvard.edu/urn-3:HUL.InstRepos:dash.current.terms-of-use\#OAP

\section{Share Your Story}

The Harvard community has made this article openly available.

Please share how this access benefits you. Submit a story.

Accessibility 


\title{
Journal of Tort Law
}

Volume 4, Issue 2

2011

Article 5

\section{Modularity and Morality in the Law of Torts}

\author{
Henry E. Smith*
}

*Harvard Law School, hesmith@law.harvard.edu

Copyright (c)2011 Berkeley Electronic Press. All rights reserved. 


\title{
Modularity and Morality in the Law of Torts*
}

\author{
Henry E. Smith
}

\begin{abstract}
Tort law presents a puzzle from an information cost point of view. Like property, its duties often avail against others generally, but unlike property it is appears not to be standardized and is more subject to judicial innovation. This essay argues that torts, like property, employs modular structures to manage the complexity of interactions between actors. Both property and torts solve the information cost problem with "in rem" rights in similar ways, by chopping up the world of interactions between parties into manageable chunks-modules-that are semi-autonomous. Instead of employing "things" to achieve modularity, tort law employs other strategies to limit information costs, by hiding information and making tort law less context-dependent than one might expect from a "law of actions." The features of tort law emphasized by noneconomic theories of tort law-corrective justice, civil recourse, and natural rights—can be seen as managing the complexity of tort law. These include tort's bilateral structure, the content of duties, and proximate cause. As in property, a heavy reliance in tort law on simple moral norms, which are easy to communicate and self-enforce, receives a partial explanation in terms of information costs. Economic analysis and broadly moral theories of torts turn out to be closer together at the descriptive level than is usually thought.
\end{abstract}

${ }^{*}$ Henry E. Smith is Fessenden Professor of Law, Harvard Law School. Please send correspondence to hesmith@law.harvard.edu. For helpful comments, the author would like to thank Lisa Austin, Richard Epstein, Michael Heller, Andrew Gold, John Goldberg, Greg Keating, and participants at the Property, Tort \& Private Law Theory Conference at the University of Southern California Gould School of Law. 


\section{INTRODUCTION}

Tort law protects many in rem rights, including not only property rights but rights of bodily integrity, reputation, and the like. This in rem character of tort is, however, quite puzzling, when we compare torts to property. Property rights are at their core in rem rights good against the world and send a message - for example the message to "keep off" in trespass to land - to a broad and indefinite audience of duty bearers. These far-flung parties would face large information costs if they had to process idiosyncratic duties. To lessen the information costs of in rem rights, the numerus clausus principle - namely the fixed list of property rights - limits customization by parties and channels innovation in the forms of property away from courts and towards legislatures. ${ }^{1}$ But if the in rem character of property has been invoked to explain the standardization of property, where does this leave the law of torts? Even though it too is often in rem, ${ }^{2}$ tort law is not standardized in this way. There is no numerus clausus of torts, and courts have not hesitated to innovate in tort law, even by creating new torts. So how does tort law manage information costs?

This essay will argue that torts is more similar to property once we bring information costs into the picture, and doing so has the potential of bringing economic and moral theories of torts closer together. Both property and torts face a problem of information costs, one that is acute because of the in rem nature of many of the rights in both areas. The main difference between property and torts is in their basic unit of analysis: property initially focuses on things and works out from there, whereas tort law takes more direct aim at acts and activities (which I will lump together as "actions"), in the sense that it focuses on conduct that potentially causes injury to others. Nonetheless, I will argue that tort law employs strategies to limit information costs, by hiding information and making tort law less context-dependent than one might expect from a "law of actions." Indeed, features of tort law emphasized by noneconomic theories of tort law, including its bilateral structure, the content of duties, and proximate cause, can be seen as managing the complexity of tort law. As in property, a heavy reliance in tort law on simple moral norms, which are easy to communicate and self-enforce, receives a partial explanation in terms of information costs.

\footnotetext{
${ }^{1}$ Thomas W. Merrill \& Henry E. Smith, Optimal Standardization in the Law of Property: The Numerus Clausus Principle, 110 YALE L.J. 1, $42-58$ (2000).

${ }^{2}$ I am using "in rem" here to denote "availing against other generally," or with larger and more indefinite classes of duty bearers than (in personam) contract, which is the sense that matters for information costs. For an analysis of the concept "in rem" and an evaluation of some other proposals, see Thomas W. Merrill \& Henry E. Smith, The Property/Contract Interface, 101 COLUM. L. REV. 773, 780-89 (2001).
} 
Both property and torts solve the information cost problem with in rem rights in similar ways, by chopping up the world of interactions between parties into manageable chunks - modules - that are semi-autonomous. ${ }^{3}$ Complex systems are ones in which small local changes can lead to unpredictable changes elsewhere in the system. ${ }^{4}$ But where a complex system is what Herbert Simon termed "nearly decomposable," we can find clusters of elements with intense mutual interactions but relatively sparse interactions between the members of such clusters and other clusters. If so, module boundaries can be drawn so that interactions are intense within the module but sparse and constrained between modules, with much information hidden within the module and sealed off from the rest of the system through limited interfaces. Think of the components of a car: the fuel injector's subparts interact with each other much more intensely than they as a group do with the rest of the car (e.g. the brakes). Modularity has been important in evolutionary theory, ${ }^{6}$ computer hardware, ${ }^{7}$ software, ${ }^{8}$ cognitive science, ${ }^{9}$ and many other areas.

${ }^{3}$ See, e.g., Herbert A. Simon, The Sciences of the Artificial 195-98 (2d ed. 1981); Richard N. Langlois, Modularity in Technology and Organization, 49 J. ECON. BeHAV. \& ORG. 19, 24-26 (2002). This is sometimes called "factoring" and sometimes finding "community structure." See, e.g., Aaron Clauset, M.E.J. Newman \& Christopher Moore, Finding Community Structure in Very Large Networks, 70 PhYs. ReV. E 70, 066111 (2004); M.E.J. Newman, Modularity and Community Structure in Networks, 103 PROC. NATL. ACAD. SCI. USA 8577 (2006).

${ }^{4}$ Simon defines a complex system informally as:

one made up of a large number of parts that interact in a nonsimple way. In such systems the whole is more than the sum of the parts, not in an ultimate, metaphysical sense but in the important pragmatic sense that, given the properties of the parts and the laws of their interaction, it is not a trivial matter to infer the properties of the whole.

SIMON, supra note 3, at 195.

${ }^{5} I d$. at 195-98 (describing a nearly decomposable system as one "in which the interactions among the subsystems are weak but not negligible"). See also 1 CARLISS Y. BALDWIN \& KIM B. ClARK, Design Rules: The Power of Modularity (2000); Managing in the Modular Age: ARCHITECTURES, NETWORKS AND ORGANIZATIONS (Raghu Garud et al. eds., 2003).

${ }^{6}$ See, e.g., Lauren W. Ancel \& Walter Fontana, Plasticity, Evolvability, and Modularity in RNA, 288 J. EXPERIMENTAL ZOOLOGY 242, 281 (2000) (suggesting that modularity arises from environmental canalization of RNA); Nadav Kashtan \& Uri Alon, Spontaneous Evolution of Modularity and Network Motifs, 102 Proc. NAT'L ACAD. SCI. U.S.A. 13773, 13777 (2005) (finding that "modularly varying goals" in biological networks can lead to "spontaneous evolution of modular network architectures"); Günter P. Wagner \& Lee Altenberg, Complex Adaptations and the Evolution of Evolvability, 50 EVOLUTION 967, 972-74 (1996) (reviewing multiple genetic models to explain modular design's evolutionary origin).

${ }^{7}$ See BALDWIN \& CLARK, supra note 5, at 149-217.

${ }^{8}$ See, e.g., Grady Booch, Object-Oriented Analysis and Design (2d ed. 1994); Edward YOURDON, OBJECT-ORIENTED SYSTEMS DESIGN: AN INTEGRATED APPROACH (1994).

${ }^{9}$ See, e.g., JERry A. Fodor, ModUlarity of Mind: AN ESSAY ON FACUlTy PSYCHOlOGY (1983) (setting forth classic theory of modularity of mind); H.C. Barrett \& R. Kurzban, Modularity in 
In the case of property, this division into chunks tracks the "things" of property, making the thing mediate between right holders and duty bearers and allowing the interaction to be less informationally intense than it would otherwise be. ${ }^{10}$ By keeping off Blackacre, I respect a wide range of interests in use that the owner might have, including growing crops, relaxing, and what not, without needing to know what these interests are or even who the owner is. Likewise with a car parked in a parking lot that I know is not mine: all I have to do is not take it or damage it. ${ }^{11} \mathrm{Up}$ to a point, tort law protects property entitlements through trespass, conversion and the like, and these torts take on the simplicity and standardization of the property entitlements they protect.

Outside of the protection it affords property entitlements, the law of torts cannot rely so heavily on the notion of a thing to manage the complexity of interactions. While property employs things as the basic unit of analysis, torts by contrast focuses in on actions. But this does not mean that tort law is totally unconstrained in its handling of complexity. Like property law, the law of torts relies heavily on modularity - semi-autonomous components and interfaces with information-hiding - in order to manage complexity. It does this through devices like the duty rules and a focus on some variables to the systematic exclusion of others. Importantly, tort law reduces information costs by relying on intuitive notions of what duties we owe each other. Just as property relies on simple widespread moral rules against theft in its most in rem aspects, ${ }^{12}$ so too does tort. Where tort prescribes rights and duties between wide and heterogeneous classes of actors, it tends to rely on simple, highly available moral intuitions that are good candidates for natural rights. The very structures emphasized outside law and economics - whether for reasons of corrective justice, ${ }^{13}$ civil recourse, ${ }^{14}$ or natural rights ${ }^{15}$ - are highly compatible with an information cost explanation.

Cognition: Framing the Debate, 113 PSYCH. REV. 628 (2006) (reviewing the modularity of mind debate).

${ }^{10}$ Henry E. Smith, Intellectual Property as Property: Delineating Entitlements in Information, 116 YALE L.J. 1742 (2007).

${ }^{11}$ See J.E. PenNER, THE IDEA OF Property In LAW 75-76 (1997).

${ }^{12}$ Thomas W. Merrill \& Henry E. Smith, The Morality of Property, 48 WM. \& MARY L. REV. 1849, 1867 (2007).

13 See, e,g., Jules L. Coleman, Risks and Wrongs (1992); Arthur Ripstein, Equality, Responsibility and the LaW (1999); ERnest J. Weinrib, The Idea of Private LaW (1995); Richard A. Epstein, A Theory of Strict Liability, 2 J. Legal Stud. 151 (1973); Stephen R. Perry, The Moral Foundations of Tort Law, 77 IowA L. REV. 449 (1992).

${ }^{14}$ See, e.g., John C.P. Goldberg, The Constitutional Status of Tort Law: Due Process and the Right to a Law for the Redress of Wrongs, 115 YALE L.J. 524 (2005); John C.P. Goldberg \& Benjamin C. Zipursky, Torts as Wrongs, 88 TEXAS L. Rev. 917 (2010); Benjamin C. Zipursky, Civil Recourse, Not Corrective Justice, 91 GEO. L.J. 695 (2003).

${ }^{15}$ See, e.g., Eric R. Claeys, Jefferson Meets Coase: Land-Use Torts, Law and Economics, and Natural Property Rights, 85 Notre Dame L. Rev. 1379 (2010); Andrew S. Gold, A Moral Rights 
As a result, debates in torts can be seen in a new and different light. Rights-based tort theories do not have a monopoly on explanation of doctrine. Law and economics, suitably broadened to take into account information costs, need not run against the grain of the legal practice of torts as understood by its participants - a common complaint heretofore against viewing tort law through the lens of law and economics. ${ }^{16}$ By the same token, law and economics should not dismiss the structures of rights and duties immanent in tort law or try to assimilate tort to regulation. ${ }^{17}$ All of which is not to deny that there are important differences that remain between deontological or legal formalist theories of torts on the one hand and the economic analysis of tort law on the other. But it does suggest their practical congruence and focuses the disagreements more at the level of foundations, where they belong.

Part I will set out the information cost puzzle posed by tort law. I will show that tort law, like property law, is formal in the sense of being less than fully responsive to contextual information. In Part II, I show how tort law breaks complex interactions between parties into manageable chunks - modules - such that information is partially hidden from some parts of the system of tort law. Unlike property, tort law takes the action as a basic unit of analysis. It uses bilateral rights and duties, rules of proximate cause, privity, and the like to achieve a degree of formalism that reduces complexity. Tort law has moved away from some of these devices, especially rules based on privity, but has only done so half-heartedly, inconsistently, and without an appreciation of foregone benefits of modularity. Part III will show that the law of torts draws on everyday morality to achieve the simplicity of formal modular structures. If so, then a law and

Theory of the Private Law, 52 WM. \& MARY L. REV. 1873 (2011); see also Gregory C. Keating, Is Tort a Remedial Institution? (USC CLEO Research Paper No. C10-11; USC Law Legal Studies Paper No. 10-10, July 1, 2010), available at SSRN: http://ssrn.com/abstract=1633687.

${ }^{16}$ See, e.g., Jules L. Coleman, The PRACTICE OF PrinCIPle 16-27 (2001) (arguing that economic analysis fails to capture the use of deontic concepts in tort law and that a theory of torts must take the internal point of view of the participants in the practice); Benjamin C. Zipursky, Sleight of Hand, 48 WM. \& MARY L. REV. 1999, 2003-04 (2007) (arguing that economic analysis fails to capture the reality of the test for negligence); see also STEPHEN A. SMITH, CONTRACT THEORY 14$24,122-23$ (2004) (arguing that a theory of law must explain legal actor's internal point of view and capture the "law's self-understanding, and that economic analysis fails in this regard"); but cf. Jody S. Kraus, Transparency and Determinacy in Common Law Adjudication: A Philosophical Defense of Explanatory Economic Analysis, 93 VA. L. REV. 287 (2007) (arguing that economic explanation is consistent with courts' use of moral and fairness-based language).

${ }^{17}$ For a sympathetic discussion and extensions, see Kyle D. Logue, Coordinating Sanctions in Tort, 31 CARDOZO L. REV. 2313 (2010). As is often the case, law and economics is following the tradition of Legal Realism. See Leon Green, The Duty Problem in Negligence Cases: II, 29 Colum. L. REV. 255, 255 (1929) (advocating replacement of traditional duty rules with policybased duty factors); see also Rowland v. Christian, 443 P.2d 561 (Cal. 1968) (adopting duty factors). 
economics incorporating information costs dovetails with accounts of tort law based on corrective justice, civil recourse, and natural rights. The use of everyday morality to make a system of coordination possible is shared by tort law and property law, although the particular strategies as well as the rights and duties differ, in part because the two areas of law employ different starting points: things versus actions.

The account of tort law offered here is compatible with a wide range of deontological theories, including some forms of utilitarianism, but is inconsistent with a view of tort law as implementing a case-by-case cost-benefit test that has unconstrained access to contextual information. Property law shows a similar relationship to morality. ${ }^{18}$ The information cost version of the economic analysis of torts is thus consistent with the structure of tort law, including such aspects as duty rules that have seemed to be the unique preserve of corrective justice, civil recourse, and natural rights theories. Because these approaches and information cost economics can both explain and partially justify the overall architecture of tort law, their disagreement must be located at a more foundational level.

\section{An Information Cost Puzzle About Torts}

Tort is puzzling at first from an information cost point of view. It is in rem, like property. In property, the in rem nature of the rights and their correlative duties forms the basis for an explanation of the mandatory standardization of property. But torts are not standardized in the same way; courts do not defer to legislatures in devising new forms of tort, as they do in property. ${ }^{19}$ There is no numerus clausus of torts, or at least not to the same degree as in property. To be sure, the basic torts of assault, battery, false imprisonment, trespass to land and chattels, conversion, nuisance, malpractice, libel, and slander date back centuries, and as with the basic property forms, courts have felt free to change (or discover) new content for these categories over time. And yet there are some important differences between torts and property in terms of the degree of formalization and standardization. First, a central tort, negligence, is open-ended in a way that property forms are not. Second, the judicial innovations that have occurred in the inventory of torts, like invasion of privacy, intentional infliction of emotional distress, and strict products liability (to the extent it really is that different from older theories of negligence), are more central to tort law than the more peripheral judicial innovations in property, such as the equitable servitude, the right of publicity, and hot news misappropriation - that is, in non-possessory and non-

\footnotetext{
${ }^{18}$ See Merrill \& Smith, supra note 12.

${ }^{19}$ On the institutional choice implications of the numerus clausus and the deference of courts to legislatures in terms of creating new basic property forms, see Merrill \& Smith, supra note 1, at 58-68.
} 
core intellectual property, often with very limited in rem effect. ${ }^{20}$ Third, when judicial innovation has occurred, there has been a rush to ratify it with

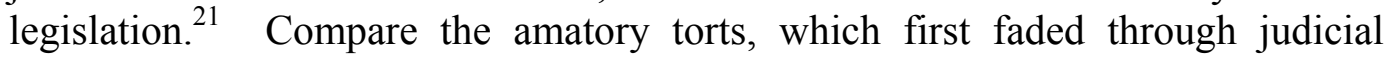
desuetude, with the Married Women's Property Acts, which abolished marital interests of surviving wives and husbands (dower and curtesy, respectively) but at the same time replaced them with the spousal elective forced share. Because of the need for people to plan and to navigate property interests it would have been very difficult for courts to have effected this change on their own. ${ }^{22}$ Torts is less standardized and formalized than property, even though it too like property often casts duties on large and indefinite classes of persons (one sense of "in rem").

Does tort law's combination of in rem effect without explicit standardization disprove the information cost account of standardization in property? Or does it mean that the law of torts is fundamentally misguided in not being standardized enough? Later I will argue that neither is true, because tort law does minimize information costs in a fashion that resembles - but is not identical with - the strategies adopted in property law. But first we need a clearer picture of how property and tort compare, especially with respect to information costs.

\section{A. Property versus Torts}

How is property standardized and what does this mean for torts? Property comes in a closed list of approved forms. The estates in land and future interests are limited to the familiar "catalog" - fee simple, defeasible fees, life estate, and their corresponding future interests, as well as the types of leases, the types of easements, and other servitudes. ${ }^{23}$ Limiting the forms of property to this set means that in rem duty bearers have fewer dimensions of information to be on the lookout for. For example, once one knows that A owns Blackacre in fee simple, one need not inquire as to whether $\mathrm{A}$ owes rent to anyone. Various sets of potential duty bearers have different interests in information relating to property. Successors in interest need the most information because they want to know what they are acquiring. Potential violators of entitlements (trespassers and the like)

${ }^{20}$ See Merrill \& Smith, supra note 1, at 16-20.

${ }^{21} I d$. at 20.

${ }^{22} I d$. at 15, 64-65 (discussing changes in martial property interests from an information cost and institutional choice point of view).

${ }^{23}$ See Merrill \& Smith, supra note 1, at 12-20; see also Thomas F. Bergin \& PAUL G. HASKell, PREFACE to Estates IN LAND AND FutURE InTERESTS $19-80$ (2d ed. 1984). The menu of basic forms could be shorter. See, e.g., T.P. Gallanis, The Future of Future Interests, 60 WASH. \& LEE L. REV. (2003) (proposing reforms for the estate system); Lawrence W. Waggoner, Reformulating the Structure of Estates: A Proposal for Legislative Action, 85 HARV. L. REV. 729, 732 (1972) (proposing simplified system of estates). 
need to know how to avoid liability or what the consequences of incurring liability are. And other people generally need to know what dimensions of information are of concern. Recording or registering property does not necessarily solve these problems. ${ }^{24}$ Transactors - the other market participants and even successors in interest - can benefit from having information presented in a mandatory standardized format. ${ }^{25}$

One reason that standardization works well in property is that it relies on things and the Lego-block-like generative quality of rights to them. Right holders and duty bearers in property interact through the thing because rights and duties are defined in terms of things. To take the familiar example mentioned earlier, when I encounter cars in a parking lot, I know not to take one if none of them belong to me, not to damage them, and so forth. ${ }^{26}$ Who the owners are and what their uses of the cars might be are irrelevant to my duty, as is any personal information about me (outside of narrow contexts like necessity). When the ownership of a car is transferred from one owner to another or when it is subjected to a security interest, my duty to respect the property rights in the car under the law of conversion and trespass to chattels does not change at all. Thus, the conventional wisdom may be correct that rights avail against people, but the role of the thing in property is crucial in keeping delineation costs down. It does so by forming the formal basis for property rights, thereby mediating the relationship between right holders and duty bearers in a simple and impersonal fashion. Limiting property to a small number of forms does not pose major problems, because the property forms can be mixed and matched in generative fashion: ${ }^{27}$ think of a life estate followed by a life estate followed by a remainder not to mentions trusts, partnerships, and corporations.

The relative simplicity and non-personalism of property rights compared to contract rights can be regarded as an instance of a type of formalism. The word "formalism" has been used in many ways, but the sense that I adopt here is "relative invariance to context." 28 The language of first-order logic is more formal than English because it requires less context in the determination of meaning. Everyday English that involves many pronouns and much use of conversational implicature is less formal than some forms of written English.

\footnotetext{
${ }^{24}$ See Merrill \& Smith, supra note 1, at 43-45. Suggestive in this regard is that there is a correlation between the definitiveness of the land records and the stringency of the numerus clausus (fewer allowed forms). See Benito Arrunada, Property Enforcement as Organized Consent, 19 J.L. ECON \& ORG. 401 (2003).

${ }^{25}$ See Henry E. Smith, The Language of Property: Form, Context, and Audience, 55 Stan. L. REV. 1105, 1167-73 (2003).

${ }^{26}$ See PENNER, supra note 11, at 75-76.

${ }^{27}$ Merrill \& Smith, supra note 1, at 35-38.

${ }^{28}$ Francis Heylighen, Advantages and Limitations of Formal Expression, 4 Foundations OF SCIENCE 25, 49-53 (1999).
} 
Conversational implicature allows ones to conclude that "It's cold in here" is a request to close a nearby window. ${ }^{29}$ Implicature relies on both elements of the context (the presence of a nearby window, how it works, and knowledge in the addressee of these facts and acceptance of the cooperative approach to conversation). A more formal - not to say completely context-free or fool-proof alternative would be to spell out the request to close the window in detail. Similarly, pronouns require context for their interpretation, and this is why legalese tends to repeat noun phrases ("the party of the first part agrees with the part of the second part that the party of the first part ...."). ${ }^{30}$ Sociolinguists have studied patterns of formalism based on the relative frequency of parts of speech: formal speech relies proportionately more on nouns, determiners, and prepositions than does informal speech, which uses relatively more context-dependent pronouns and adverbs. ${ }^{31}$ Importantly, under this definition, formalism is a matter of degree. Thus, a common Legal-Realist-inspired move is to conclude from the need to rely on some context that context should always be available. ${ }^{32}$ Context is never completely eliminable but it is a functional question how much to make available. $^{33}$ In particular, in communicating with a wide and heterogeneous audience, it makes sense to be more formal, in the sense of less reliance on context. $^{34}$

Because it makes some contextual information less relevant, standardization in property through the numerus clausus, and especially by means of defining rights in terms of things, presents an important instance of "formalism." Formalism is also at stake in the debate over the proper role of custom in law. One major difference between law and custom is relative reliance on context, because custom can presuppose more background knowledge of the

\footnotetext{
${ }^{29}$ H.P. Grice, Logic and Conversation, in 3 SyntaX And Semantics 41 (Peter Cole \& Jerry L. Morgan eds., 1975), reprinted in PAUL GRICE, STUdies In THE WAYS OF WORDS 22, 26 (1989).

${ }^{30}$ See Peter M. Tiersma, Legal Language 71-73 (1999). The use of pronouns is a familiar aspect of context-dependence (called indexicality) and is one component of Dewaele's constructed variable of formalism. See infra note 31 and accompanying text.

${ }^{31}$ See, e.g., Jean-Marc Dewaele, How to Measure Formality in Speech: A Model of Synchronic Variation, in APproaches to SeCond LANGUAGe ACQUisition (Kari Sajavaara \& Courtney Fairweather eds., 1996); see also Jean-Marc Dewaele, Style-shifting in oral interlanguage: quantification and definition, in THE CURRENT STATE OF INTERLANGUAGE: STUDIES IN HONOR OF WiLLIAM E. RUTHERFORD (Lynn Eubank, Larry Selinker, \& Michael Sharwood Smith eds., 1995); see also Smith, supra note 25, at 1135-36.

${ }^{32}$ Id. at 1179-84; Henry E. Smith, Modularity in Contracts: Boilerplate and Information Flow, 104 Mich. L. REV. 1175, 1214-19 (2006).

${ }^{33}$ See, e.g., Alan Schwartz \& Robert E. Scott, Contract Theory and the Limits of Contract Law, 113 YALE L.J. 541 (2003); Smith, supra note 25, at 1167-90.

${ }^{34}$ Id. at 1125-67; Smith, supra note 32, at 1203-07.
} 
members of the community in which it prevails. ${ }^{35}$ Whalers and miners knew more about whaling and mining norms (respectively) than did members of the general public. $^{36}$ Again, formalism is a matter of degree, or what I have called elsewhere "differential formalism.",37

Property law in this sense tends to be more formal than contract law. As mentioned earlier, contractual interpretation will allow for parties to adopt idiosyncratic meanings that are only discoverable with reference to the parties' contract or their dealings. Although different contracts call for different levels of formalism and different parties have different preferences for how formal the interpretive methodology should be, property on the whole tends to be more mandatorily formal than contract. ${ }^{38}$ Contract rights when they are treated as property (e.g. choses in action, assignments) are stripped of much of their personal content and are highly simplified, qua property. ${ }^{39}$ In property, the numerus clausus eliminates much potential contextual detail. Very basically, the exclusionary strategy in property is relatively context free - asking, as it does, whether there has been a boundary crossing by a visible object - and context mainly comes in around the edges, through nuisance and exceptions (such as for necessity). ${ }^{40}$ The requirements for recordation, and even more so those for registration in other systems, also impose formalism in the sense of relative invariance to context. ${ }^{41}$ Along many dimensions, property is formalized, beginning with its thingness.

\section{B. Context and Formalism in Torts}

Where does this leave torts? At first glance, it appears to be highly contextualized, and the conventional law-and-economics approach to torts makes it appear only more so. Take the tort of negligence, which has at its center the duty to take reasonable care. What is reasonable care? The notion of reasonableness appears quite open-ended. If the notion of reasonableness is

${ }^{35}$ Henry E. Smith, Community and Custom in Property, 10 TheORETICAL INQUIRIES IN LAW 5 (2009).

${ }^{36}$ Id. at 26-34.

${ }^{37}$ Smith, supra note 25 , at $1135-39,1167-90$.

${ }^{38}$ Id. at 1150-57; Smith, supra note 32 , at 1207-14.

${ }^{39}$ Merrill \& Smith, supra note 1, at 54-55.

${ }^{40}$ Henry E. Smith, Exclusion Versus Governance: Two Strategies for Delineating Property Rights, 31 J. LEGAL STUD. S453 (2002).

${ }^{41}$ See, e.g., Benito Arruñada, The Law of Impersonal Transactions (May 6, 2010), in Manufacturing Markets (Eric Brousseau \& Jean-Michel Glachant, eds., Cambridge University Press, forthcoming; UPF Economics \& Business Working Paper No. 1187), available at SSRN: http://ssrn.com/abstract=1154080. 
interpreted as calling for a cost-benefit analysis, ${ }^{42}$ as is common in law and economics and often outside it as well, then it could not be more contextual: any cost or benefit from the context in which the actor was operating would be relevant. Or consider proximate cause, which is often seen as an open-ended policy-oriented judgment. ${ }^{43}$ The tendency in law and economics is not to rule out much in principle from being relevant to the proximate cause analysis.

Nor is the contextualized view of torts confined to reading cost-benefit tests into legal rules. By the same token, cheapest cost avoider analysis - which uses economic analysis to place liability on one who is best positioned to make and act on a cost-benefit analysis - does not point to any principled limits on context. $^{44}$ Should the injurer be regarded as a generic person, a driver, a young driver, etc.? In a products liability case, how do we segment industries? In general, cheapest cost avoider analysis treats the basic question - how general categories should be - as a matter of convenience; and the considerations that determine who the cheapest cost avoider is are likewise open-ended. Who has what of an open-ended set of potentially relevant information? Who can take any of an open-ended set of actions? Who is the best insurer? The best briber?

In his introduction of the cheapest cost avoider framework, Guido Calabresi pays a great deal of attention to how in general we would figure out who is the cheapest cost avoider, and recommends a procedure involving the initial rough guess, experiments, and various rules of thumb. But what characterizes the entire approach is an unconstrained access to contextual information in formulating rules of tort liability. ${ }^{45}$ In Calabresi's formulation:

In other words, the loss bearer who can enter into transactions most cheaply must be chosen with all the cost elements involved in entering into transactions in mind, and those include not only the most obvious transaction costs, but also the costs of risk, information, and even coercion where it is the cheapest device available. ${ }^{46}$

\footnotetext{
${ }^{42}$ See, e.g., Richard A. Posner, A Theory of Negligence, 1 J. Legal StUD. 29, 32-33 (1972); see also John Prather Brown, Toward an Economic Theory of Liability, 2 J. LEGAL STUD. 323 (1973).

${ }^{43}$ See, e.g., Guido Calabresi, Concerning Cause and the Law of Torts: An Essay for Harry Kalven, Jr., 43 U. CHI. L. REv. 69, 72 (1975); William M. Landes \& Richard A. Posner, Causation in Tort Law: An Economic Approach, 12 J. Legal StUD. 109, 110-11 (1983); Steven Shavell, An Analysis of Causation and the Scope of Liability in the Law of Torts, 9 J. LEGAL STUD. 463, 464-66 (1980); see also DAN B. DOBBS, THE LAW OF TORTS, § 181, at 445 (3d ed. 2004) (proximate cause expresses a value judgment about the defendant's conduct).

${ }^{44}$ Guido Calabresi, The Costs of Accidents: A Legal and EConomic Analysis (1970).

${ }^{45} \mathrm{Id}$. at $135-59$.

${ }^{46} I d$. at 151 (emphasis in original).
} 
Smith: Modularity and Morality

The anti-formalism of this approach finds its extreme when Calabresi suggests that in principle there is no reason other than transaction costs why television manufacturers should not be strictly liable for car-pedestrian accidents. $^{47}$

But as is so often the case, law and economics, in its emphasis on contextual information, is merely traveling in a well-worn path blazed by Legal Realism. This is quite clear in property, with the adoption in law and economics of the bundle of rights theory. ${ }^{48}$ In torts, the Realist-inspired opening toward contextual information can be seen in the rise of new types of liability such as products liability and market-share liability, where context matters more in the sense that all sorts of cost-benefit variables come into play. ${ }^{49}$ Even the LegalRealist-inspired view of nuisance in the Restatement seems to call for a cost-

${ }^{47} \mathrm{Id}$. at 136 .

${ }^{48}$ Thomas W. Merrill \& Henry E. Smith, What Happened to Property in Law and Economics?, 111 YALE L.J. 357 (2001).

${ }^{49}$ Courts developing the law of products liability thought in regulatory terms, with the California Supreme Court playing a leading role. Greenman v. Yuba Power Prods., Inc. 377 P.2d 897, 901 (Cal. 1963) ("The purpose of such liability is to insure that the costs of injuries resulting from defective products are borne by the manufacturers that put such products on the market rather than by the injured persons who are powerless to protect themselves. Sales warranties serve this purpose fitfully at best.") In adopting industry share liability the same court made explicit its Realist-style policy-driven regulatory approach. Sindell v. Abbott Laboratories, 607 P.2d 924, 936 (Cal. 1980) ("In our contemporary complex industrialized society, advances in science and technology create fungible goods which may harm consumers and which cannot be traced to any specific producer. The response of the courts can be either to adhere rigidly to prior doctrine, denying recovery to those injured by such products, or to fashion remedies to meet these changing needs."). The Second Restatement distills this point of view:

On whatever theory, the justification for the strict liability has been said to be that the seller, by marketing his product for use and consumption, has undertaken and assumed a special responsibility toward any member of the consuming public who may be injured by it; that the public has the right to and does expect, in the case of products which it needs and for which it is forced to rely upon the seller, that reputable sellers will stand behind their goods; that public policy demands that the burden of accidental injuries caused by products intended for consumption be placed upon those who market them, and be treated as a cost of production against which liability insurance can be obtained; and that the consumer of such products is entitled to the maximum of protection at the hands of someone, and the proper persons to afford it are those who market the products.

RESTATEMENT (SECOND) OF TORTS § 402A cmt.c (1965). Economic analysis tends to view torts as regulation with disagreement on some of the empirical premises. See George L. Priest, Market Share Liability in Personal Injury and Public Nuisance Litigation: An Economic Analysis, 18 SuP. Ст. ECON. REV. 109, 110 (2010) ("The basic rationale for market share liability derives from the quasi-economic principle of achieving appropriate market incentives as among product manufacturers by internalizing the costs of harms caused by a product to the manufacturer that produced the harmful product."). 
benefit test, or at least an all-things-considered style of balancing. ${ }^{50}$ Post-Realists more generally have detached nuisance from its moorings in natural rights and reciprocity - as reflected in the maxim sic utere tuo ut alienum non laedas or "use your property in such a way as not to injure another's"51 - in favor if "balancing" a highly open-ended set of "factors." 52 The sic utere maxim by contrast is laughed off as being conclusory and empty - and not responsive to relevant information about particular disputes. ${ }^{53}$

As the saga of nuisance and the Restatement should suggest, courts do not in fact use all the context that they claim they have access to, ${ }^{54}$ in a fashion very

${ }^{50}$ RESTATEMENT (SECOND) OF TORTS $§ 826-28$ (1979); see also RESTATEMENT (FIRST) OF TORTS $\S \S 822,826$ (1939).

${ }_{51}$ See, e.g., Vill. of Euclid v. Ambler Realty Co., 272 U.S. 365, 387 (1926) ("In solving doubts, the maxim sic utere tuo ut alienum non laedas, which lies at the foundation of so much of the common law of nuisances, ordinarily will furnish a fairly helpful clew."); Lussier v. San Lorenzo Valley Water Dist., 253 Cal. Rptr. 470, 473 (Cal. Ct. App. 1988) ("The basic concept underlying the law of nuisances is articulated in the ancient maxim sic utere tuo ut alienum non laedas, that is, so use your own as not to injure another's property.").

${ }^{52}$ The Restatement (Second) instructs that "[i]n determining the gravity of the harm from an intentional invasion of another's interest in the use and enjoyment of land, the following factors are important: (a) The extent of the harm involved; (b) the character of the harm involved; (c) the social value that the law attaches to the type of use or enjoyment invaded; (d) the suitability of the particular use or enjoyment invaded to the character of the locality; and (e) the burden on the person harmed of avoiding the harm." RESTATEMENT (SECOND) OF TORTS $§ 827$ (1979). On the other side of the ledger, Section 828 directs courts that "[i]n determining the utility of conduct that causes an intentional invasion of another's interest in the use and enjoyment of land, the following factors are important: (a) the social value that the law attaches to the primary purpose of the conduct; (b) the suitability of the conduct to the character of the locality; and (c) the impracticability of preventing or avoiding the invasion." Id. at $\S 828$.

${ }^{53}$ See Lucas v. S.C. Coastal Council, 505 U.S. 1003, 1031 (1992) (criticizing invocation of sic utere maxim as conclusory); Hale v. Farmers Elec. Membership Corp., 99 P.2d 454, 456 (N.M. 1940) (holding that although sic utere is a good moral precept, it is useless as a grounds for decision because it does not determine any right or obligation, and citing cases and commentary to this effect). Holmes stated an early version of this critique:

But whether, and how far, a privilege shall be allowed is a question of policy. Questions of policy are legislative questions, and judges are shy of reasoning from such grounds. Therefore, decisions for or against the privilege, which really can stand only upon such grounds, often are presented as hollow deductions from empty general propositions like sic utere tuo ut alienum non laedas, which teaches nothing but a benevolent yearning, or else are put as if they themselves embodied a postulate of the law and admitted of no further deduction, as when it is said that, although there is temporal damage, there is no wrong; whereas, the very thing to be found out is whether there is a wrong or not, and if not, why not.

Oliver Wendell Holmes, Privilege, Malice, and Intent, 8 HARV. L. REV. 1, 3 (1894).

${ }^{54}$ See generally Jeff L. Lewin, Boomer and the American Law of Nuisance, 54 ALB. L. REv. 189, 212-14 (1990) (documenting the limited adoption of the balance of the utilities test for reasonableness, and citing cases); Henry E. Smith, Exclusion and Property Rules in the Law of Nuisance, 90 VA. L. REV. 965, 970 (2004). 
similar to their less than full use of cost-benefit tests in negligence. ${ }^{55}$ In nuisance cases, there is much citation of the Restatement but precious little evidence of serious cost-benefit analysis. And this is as it should be. The idea of courts acing like mini-EPAs every time a private nuisance dispute comes along is more than a little strange. Instead, much of nuisance law relies heavily on the same boundaries as does trespass, and the shift from exclusion to governance happens within the law of nuisance. ${ }^{56}$ Thus, if odors or sound waves travel from parcel A to parcel $\mathrm{B}$, it is more likely that the owner of $\mathrm{A}$ is committing a nuisance than vice versa. To Coaseans, this nonreciprocal causation looks unjustifiable, but as I have argued elsewhere, the information cost benefits of broad property rights break the causal symmetry: owners have a presumptive right to repel invasions, not vice versa, because such packages of rights solve many problems wholesale. ${ }^{57}$ Nuisance involves the fine-tuning of this exclusion-based regime though off-therack common law - other methods range from norms to servitudes to zoning and the basic property module with its boundary is the starting point.

How contextualized is torts? There is no closed list of torts, no numerus clausus, although as we will see the information cost theory helps explain the stability in the list of most torts. And, as just noted, many torts seem to call for a very contextualized inquiry. But in other ways tort law is very "formal" - as emphasized by corrective justice, civil recourse, and related approaches. Let us now turn to how the law of torts manages information costs.

\section{MANAGING INFORMATION COSTS IN TORT LAW}

The law of torts manages complexity through modular structures and formalism, but differently from property. These methods are often less natural looking than they are in property and so have come under greater pressure and have been relaxed more than in the law of property.

\footnotetext{
${ }^{55}$ See, e.g., Richard W. Wright, Justice and Reasonable Care on Negligence Law, 47 AM. J. JURIS. 143, 145 (2003) ("The aggregate-risk-utility test was created by legal academics and inserted into the first Restatement of the Law of Torts during the first part of the twentieth century, when utilitarianism was a popular moral and political theory. The test's adoption in the Restatement assured its prominence in the secondary literature and even its citation in a significant number (albeit a small minority) of judicial opinions. However, with rare exceptions, these citations have been mere lip service, as the test is not actually employed by the courts to determine whether specific conduct was negligent.").

${ }^{56}$ Smith, supra note 54, at 990-1007.

${ }^{57}$ Henry E. Smith, Self-Help and the Nature of Property, 1 J.L. ECON. \& POL'Y 69, $74-76$ (2005); see also Smith, supra note 54, at 1007-21.
} 


\section{A. The Initial Focus}

Where property starts with a thing as the beginning for delineating rights, tort law takes action as its starting point. Property begins by using the exclusion strategy to define a thing and then, depending on the circumstances, moves more or less quickly to other strategies of governing uses and making exceptions in order to refine the basic exclusionary set-up. ${ }^{58}$ Tort law takes as its basic unit of analysis the action. The rights and duties in torts are defined in terms of who should not do what to whom. This initial focus on actions makes tort look a lot like regulation, which is also aimed at action (activities in particular). Another way to draw the basic distinction between property and tort is that basic property gives the owner a general right to repel invasions (of an open-ended variety); the more purely tort perspective scrutinizes each particular invasion (or conflicting activity) and announces which ones are impermissible and which ones are permissible. Later I will turn to tort law's methods of managing the complexity of a liability system based on actions and in what senses tort counts as formal, but for now, we compare property and tort in terms of their initial focus - things and actions.

To see how tort and property compare in terms of their basic unit of analysis, it is instructive to consider how tort and property potentially apply to the same situation. Consider the first possession of wild animals. The law can start with the resource itself, say a fox, and then ask what degree of control (or alternatively, what degree of prospect) will establish first possession and thereby ownership. A familiar example, albeit somewhat artificial, ${ }^{59}$ would be Pierson $v$. Post, ${ }^{60}$ where the question is framed as who gets the fox, and more particularly what does someone have to do with respect to the fox in order to establish the claim. In particular, the majority's "certain control" test puts a heavy (although not exclusive) focus on the object itself. Establishing a claim over a resource may involve earning the claim or doing something to make clear to others that a claim is being made. Indeed, the two aspects are related: the Lockean labor-mixing theory ensures that the mixed labor communicates to potential duty bearers through the worked-upon thing. ${ }^{61}$ Generally, the communicative aspect of possession is at least somewhat mediated through the thing: acting upon the thing announces the claim. ${ }^{62}$

\footnotetext{
${ }^{58}$ Smith, supra note 40; Smith, supra note 54, at 975-90.

${ }^{59}$ See Angela Fernandez, Pierson v. Post: A Great Debate, James Kent, and the Project of Building a Learned Law for New York State, 34 LAw \& Soc. InQuiry 301 (2009); Angela Fernandez, The Lost Record of Pierson v. Post, The Famous Fox Case, 27 LAW \& HIST. ReV. 149 (2009).

${ }^{60} 3$ Cai. R. 175 (N.Y. Sup. Ct. 1805).

${ }^{61}$ Carol M. Rose, Possession as the Origin of Property, 52 U. CHI. L. Rev. 73, 78 (1985).

${ }^{62}$ Smith, supra note 25, at 1115-19.
} 
But some situations in which people are competing to own resources are not handled under the law of first possession. Instead, two or more actors are engaged in a competitive process and the law can regulate their activities vis-à-vis one another. The desired thing or resource is even more in the background, and the basic focus of the analysis is the activities of the competitors and their impact on each other. ${ }^{63}$ This approach is taken when at least one of the competitors is engaged in a trade. ${ }^{64}$ Thus, in Keeble v. Hickeringill, ${ }^{65}$ often paired with Pierson, the defendant fired guns near the plaintiff's duck decoy (a device for luring and trapping ducks). Because the ducks were not under the plaintiff's control and he could not even count them (as required at the time for a claim based on possession), the only avenue was to sue for the interference with his trade. The law would protect against the malicious activity of Hickeringill because the duck decoy was being used for commercial purposes. By the same token, Keeble would not be protected against losing ducks to Hickeringill's decoy, unless perhaps it were being operated out of pure spite. ${ }^{66}$

Is this more purely tort law approach modular, and why is it used for "first possession" cases involving trade? The first thing to notice is that tort law's approach to regulating competition is highly selective. The law presumes that competition is beneficial unless a category of competitive activity can clearly be shown to be bad overall (inefficient, if you will). ${ }^{67}$ Thus, competition involving bodily injury or pure spite tends to be found tortious, but all sorts of other variables are left out. Nor does tort law evaluate practices on the cost-benefit model of antitrust with its structure of per se rules and rules of reason.

The focus on interference with a trade makes sense in terms of a model of exclusion and governance. In property terms, the tort approach to unfair competition is more like governance: it prescribes proper activities. ${ }^{68}$ In property generally, these activities usually involve use of the resource; in competition torts, the focus is on acquisitive activities. Trade activities may be thought to be more valuable and the conflict to be more intense on average. So training this more fine-grained - although not totally unconstrained - focus on activities involving

\footnotetext{
${ }^{63}$ One can analyze these cases as involving the first possession of an opportunity, Benjamin L. Fine, An Analysis of the Formation of Property Rights Underlying Tortious Interference with Contracts and Other Economic Relations, 50 U. CHI. L. REV. 1116 (1983), but the point in the text is that in terms of delineation the activity is doing more work in the tort cases than in the first possession of property cases.

${ }^{64}$ See A.W. BRIAN SimPSON, LEADING CASES IN THE COMMON LAW 64 (1995).

${ }^{65} 103$ Eng. Rep. 1127 (Q.B. 1707).

${ }^{66}$ See, e.g., Tuttle v. Buck, 119 N.W. 946 (Minn. 1909).

${ }^{67}$ See, e.g., Harold Demsetz, Wealth Distribution and the Ownership of Rights, 1 J. Legal STUD. 223, 231-32 (1972).

${ }^{68}$ Smith, supra note 40.
} 
trade-oriented acquisitive competition is more of a priority than with competition in general.

While the general tendency of the bundle of rights theory of property is toward a relentless focus on fine-grained activities, thus assimilating property to torts, ${ }^{69}$ some theories make torts look too much like property. In so-called commodification and quasi-commodification theories of torts, ${ }^{70}$ the interests protected by a tort, such as bodily integrity or a reputation, are treated as owned things. (Likewise even in the unfair competition and tortious interference with contracts, some see a "business opportunity" as potential property to which a metaphorical version of first possession is applied. ${ }^{71}$ ) Tort law, then, is the device by which their "owners" protect these things like bodily integrity or reputations against harm (punches in the nose, lies). These theories are open to the objection that bodily integrity, reputations, and the like are not conceived of as things, ${ }^{72}$ and are not as alienable as one might expect if they were things in the property sense. (Treatment as property does not require alienability, but it does lead to a mild expectation of alienability. The systematic lack of alienability of some of these interests in torts suggests something else is going on. ${ }^{73}$ ) Instead, I will argue tort law treats the acts and activities surrounding bodily integrity and reputation in a somewhat modular, formal way, which bears some resemblance to the modular formal exclusion strategy in property (the law of "things").

\section{B. Modularity in Tort Law}

Modularity and formalism may not be as strong as they once were, but they do figure very prominently in current tort law, particularly in those aspects emphasized outside of law and economics. Let us consider some of the more salient features of tort law that contribute to its modularity.

\footnotetext{
${ }^{69}$ Merrill \& Smith, supra note 48, at 378-79 (tracing tort perspective on property as outgrowth in law and economics of Coase's work on social cost).

${ }^{70}$ John C.P. Goldberg \& Benjamin C. Zipursky, Rights and Responsibility in the Law of Torts, in Rights AND PRIVATE LAW (Donal Nolan \& Andrew Robertson eds., Hart Publishing, forthcoming 2011), at *11-12.

${ }^{71}$ See Fine, supra note 63.

${ }^{72}$ Goldberg \& Zipursky, supra note 70, at *11-12. Goldberg and Zipursky also point out that such theories rely too heavily on the notion of "making whole." Id.

${ }^{73}$ The point is merely suggestive, because there are examples of property (e.g. professional licenses) that cannot be alienated, and some theorists even treat contracts as involving property rights to performance. See Peter Benson, Contract as a Transfer of Ownership, 48 WM. \& MARY L. REV. 1673 (2007); Andrew S. Gold, A Property Theory of Contract, 103 Nw. U. L. ReV. 1 (2009). At the least, contracts tend to be standardized like property when they are treated as alienable. See Merrill \& Smith, supra note 1, at 54-55; J.E. Penner, The "Bundle of Rights" Picture of Property, 43 UCLA L. REV. 711, 802-03, 810-13 (1996); see also Smith, supra note 25, at $1166 \&$ n.215.
} 


\section{Bilateral Rights and Duties}

One of the most striking features of tort law, and one which differentiates it from regulation or social insurance, is its bilateral structure. ${ }^{74}$ Tort claims run between a right holder and a duty bearer. A has a right not to be punched in the nose by $\mathrm{B}$, and if $\mathrm{B}$ does punch $\mathrm{A}$ in the nose, $\mathrm{A}$ has a right to sue $\mathrm{B}$ for battery. Certainly tort litigation is framed as a contest between a plaintiff and a defendant, with variations for multiple-party litigation. As many theorists have pointed out, this bilateral structure is deeply engrained in tort law. This bilateral structure is the jumping off point for corrective justice theories of torts.

How is tort law modular and formal? All the features that make corrective justice or recourse theory attractive can be interpreted as ruling out whole categories of context, thereby making tort law more formal in the sense of relative invariance to context. ${ }^{75}$

Consider the law of negligence. The relationality of breach makes the duty in negligence bilateral and reduces information costs. In the landmark case of Palsgraf v. Long Island Railroad, ${ }^{76}$ plaintiff Helen Palsgraf was hit on the head by falling scales that had been tipped over by an explosion on the other side of the platform resulting from a package of fireworks hitting the rails, which had been dislodged by two employees of the defendant railroad who, unaware of its contents, were helping a passenger aboard a departing train. Chief Judge Cardozo's majority opinion holds that breach is relational: one cannot be liable for negligence unless one's duty runs to the plaintiff on the basis of being in a class of foreseeably injured persons. Foreseeability thus cuts off inquiry into context wholesale. It should be noted that a concern with information costs does not uniquely point to the result in Palsgraf. Judge Andrews' dissent in Palsgraf may be less formal or modular, but not completely so. If one endorses a zone of negligence, much depends on how that zone is constructed. ${ }^{77}$ Contextual

\footnotetext{
${ }^{74}$ See, e.g., COLEMAN, supra note 16, at 21; WeINRIB, supra note 13, at 1-55.

${ }^{75}$ See supra notes $28-34$ and accompanying text.

${ }^{76} 162$ N.E. 99 (N.Y. 1928).

${ }^{77}$ Judge Andrews would allow in a greater amount of context in the determination of negligence:
} There are no fixed rules to govern our judgment. There are simply matters of which we may take account. We have in a somewhat different connection spoken of 'the stream of events.' We have asked whether that stream was deflected - whether it was forced into new and unexpected channels. This is rather rhetoric than law. There is in truth little to guide us other than common sense. . . Clearly we must so consider, for the greater the distance either in time or space, the more surely do other causes intervene to affect the result. When a lantern is overturned, the firing of a shed is a fairly direct consequence. Many things contribute to the spread of the conflagration - the force of the wind, the direction and width of streets, the character of intervening structures, other factors. We draw an uncertain and wavering line, but draw it we must as best we can.

Id. at 104 (Andrews, J., dissenting) (citation omitted). 
information outside the zone is ruled out, and at a more meta-level if it were possible to draw a bright-line zone of negligence, that would be a fairly formal approach as well. By contrast, a free floating, policy driven, and freely updatable standard of negligence "in the air" would be far less formal and would carry with it higher information costs for primary actors and courts. ${ }^{78}$

Further, tort duties are not as open-ended as they appear at first sight. As just noted, the duty of care in negligence is limited in various ways, so that whole categories of contextual information are not relevant, including entire classes of potentially harmed parties. And, as discussed in the next part, common law tort duties tend to track everyday morality, making them easier to convey and to selfenforce. Duties that are imposed very widely should not and do not require special expertise.

\section{Bilateral Care}

A modular structure for tort law has the potential to solve one of the problems of models built more directly on the costs and benefits of precaution. Consider some features of negligence more specifically. The bilateral structure of rights and duties does narrow down information, but as economic analyses of negligence (and strict liability) have shown, even capturing the incentives for bilateral care and prescribing a rule that gives the correct incentives, especially in any robust fashion, is extremely difficult.

Most economic analysis of tort law sees some version of a cost-benefit test in the rules of negligence. The Hand Formula and Richard Posner's elaboration of it are interpreted as embodying a cost-benefit test for precautions: due care is met if the defendant adopted all precautions that are less costly than accidents thereby prevented discounted by their probability of occurrence. ${ }^{79}$ Others have pointed out that strict liability also gives an efficient incentive for precaution, and is equivalent in deterrence terms to negligence if it is paired with a defense of contributory negligence. ${ }^{80}$ Under either system, the residual liability is said to be best placed on the one whose activity level is most important to accidents. ${ }^{81}$

\footnotetext{
${ }^{78}$ Judge Andrews probably had in mind something in between: "A cause, but not the proximate cause. What we do mean by the word 'proximate' is that, because of convenience, of public policy, of a rough sense of justice, the law arbitrarily declines to trace a series of events beyond a certain point. This is not logic. It is practical politics." Id. at 103.

${ }^{79}$ United States v. Carroll Towing Co., 159 F.2d 169, 173 (2d Cir. 1947); see, e.g., WiLliam M. Landes \& Richard A. Posner, The Economic Structure of Tort LaW 291-92 (1987); Richard A. Posner, A Theory of Negligence, 1 J. Legal StUD. 29, 32-33 (1972).

${ }^{80}$ Richard A. Posner, Strict Liability: A Comment, 2 J. Legal STUD. 205, 221 (1973).

${ }^{81}$ Steven Shavell, Strict Liability Versus Negligence, 9 J. Legal StUD. 1 (1980).
} 
Unless the care (and activity level) of one of the parties is irrelevant to the accident, models need to incorporate bilateral incentives for care. ${ }^{82}$

The problem is that these models are not robust, in that small deviations from the optimum on the part of either injurers or victims can make the models unravel. $^{83}$ In Simon's terms, the economic analysis of negligence and strict liability is highly non-modular. Small changes in one part of the "system" - one of the actor's activities - can lead to highly unpredictable overall results. ${ }^{84}$

One solution is to recognize that the system of actors and their actions is what Simon called a "nearly decomposable system." 85 Not a completely decomposable system, but one which can be divided up into semi-autonomous components without losing too much functionality. Thus, as Steve Shavell has pointed out, some choices can be made without knowledge of the other party's optimal care level (for example, using a light while riding a bicycle at night reduces accidents regardless of the exact level of care of drivers), and discrete choices make the formal model of negligence less fragile. ${ }^{86}$ If taking care involves discrete actions (like wearing a light) or levels of care like high, medium, and low, the other party's decision will be much simpler because more robust. On

${ }^{82}$ See, e.g., Robert Cooter, Unity in Tort, Contract, and Property: The Model of Precaution, 73 CAL. L. REV. 1 (1985).

${ }^{83}$ Shawn J. Bayern, The Limits of Formal Economics in Tort Law: The Puzzle of Negligence, 75 BROOKLYN L. REV. 707 (2010).

${ }^{84}$ See supra note 4 and accompanying text. Highly interdependent contextual information is required. STEVEN SHAVELl, FoUNDATIONS OF ECONOMIC ANALYSIS 188 (2004) ("“T]o ascertain the optimal level of due care for just one party, a court must generally determine (if only implicitly) the optimal level of care for the other as well, because the optimal level of care for one party will in principle depend on the other's cost of, and possibilities for, reducing risk."); $i d$. at $188 \mathrm{n} .17$ (noting that on his model "courts must generally consider the entire tableau of costs and effectiveness of care for the two parties to determine optimal care for either"). As Bayern points out, this can be taken to mean that small changes in any one of a host of variables can have large effects on what a court should take to be optimal precaution. Bayern, supra note 83, at 732 n.68. This describes a nonmodular complex system. See also id. at $738 \mathrm{n} .83$ (noting that the bilateral precaution system is "chaotic," in both the lay and technical sense).

${ }^{85}$ See supra note 5 and accompanying text. Property imposes a modular system on a nearly decomposable system of activities. See Henry E. Smith, Institutions and Indirectness in Intellectual Property, 157 U. PA. L. REV. 2083, 2089-90, 2094-95 (2009); Smith, supra note 40, at S468-71; see also Robert C. Ellickson, Property in Land, 102 YALE L.J. 1315, 1322-28 (1993) (setting out framework of size of events and corresponding property regimes); Lee Anne Fennell, Property and Half-Torts, 116 YALE L.J. 1400, 1436-38 (2007) (proposing metaphor for property of leaky bucket of bets); Dean Lueck, The Economic Nature of Wildlife Law, 18 J. LEGAL STUD. 291, 301-02 (1989) (modeling property on multiple scales and noting how large scale uses may require some modification of a regime that is geared towards important uses on a smaller scale).

${ }^{86}$ SHAVELL, supra note 84, at 179, 188 n.17; Bayern, supra note 83, at 738-40. Shavell relies more on the notion that the continuous model is a useful "as if" model that captures a lot of factors involved in the implicit decision making on the part of the parties and courts. SHAVELL, supra note 84 , at 191-92. 
our terms the interface between the two actors is simpler if the possibilities only of high, medium, and low levels of care need to be matched on both sides.

To this we can add that tort law rules out categorically many potential variables, as explored by James Anderson. ${ }^{87}$ The selection of variables to include implicates administrative and information costs. ${ }^{88}$ Likewise, if the negligence standard, instead of embodying the Hand formula, in practice really does ask people to act with "ordinary care," or as a person of ordinary prudence would act, this may have the effect of harnessing everyday intuitions and morals (to which I return in Part III). ${ }^{89}$ I leave it as a question for further work as to whether ruling out the variables that tend to be left out does have the effect of modularizing the system of actors and actions, and in particular whether it does so approximately well. If so, modularization would be a powerful explanation for why the actual structure of tort law is as selective as it is. By the same token, as I will discuss in the next Part, the variables that are ruled in are those that accord with morality and everyday intuition. If so, this is yet another reason to think that, for reasons of information cost and modular structure, the economic and noneconomic theories of torts are closer together "at the surface" than they at first appear.

Finally, tort law inherits some modularity from property itself. As noted earlier, trespass and even negligence track and make use of real property boundaries. But the modularity of property structures carries over into torts in more surprising ways centering around bilateral rights and duties.

Commentators on tort law, from Coase onward, often take as their prime example of bilateral care the train emitting sparks and the farmer stacking hay or growing crops on his land near the track. ${ }^{90}$ Commentators treat the problem as one of competing activities and see the law's task as giving proper incentives for care to railroads and farmers. Interestingly, the law is far from working this way.

The specific rule that governs this situation promotes the modularity of actors and their spheres of activity. The situation of trains emitting sparks and

\footnotetext{
${ }^{87}$ James M. Anderson, The Missing Theory of Variable Selection in the Economic Analysis of Tort Law, 2007 UTAH L. REV. 255 (2007).

${ }^{88}$ Giuseppe Dari-Mattiaci, On the Optimal Scope of Negligence, 1 REV. L. \& ECON. 331 (2005).

${ }^{89}$ See Zipursky, supra note 16, 2013-26, 2029-40 (arguing that Hand formula does not capture the concept of negligence and that some combination of aspects of theories based on convention and virtue, i.e. civil competence, captures way people actually use the concept). Pattern jury instructions are mostly formulated in terms of "ordinary care" and the person of ordinary prudence and how that person would act under the circumstances. See id. at 2013-17; Patrick J. Kelley \& Laurel A. Wendt, What Judges Tell Juries About Negligence: A Review of Pattern Jury Instructions, 77 CHI.-KENT L. REV. 587, 594-95 (2002).

${ }^{90}$ Richard A. POSNER, ECONOMIC ANALYSis OF LAW $\S \S 3.6,3.8$, at 50-52 (7th ed. 2007) (using train spark example to illustrate economic analysis of conflicting activities); Robert D. Cooter, Coase Theorem, in 1 The New PALgRave: A Dictionary of EConomics 457, 458 (John Eatwell et al. eds., 1987) (using Coase Theorem example); see also Claeys, supra note 15, at $1382 \mathrm{n} .14$ (documenting prevalence of train sparks example).
} 
adjacent fields with flammable crops (or stacked hay) is famous from Coase and has been carried forward by tort theorists as a prototypical situation calling for rules requiring bilateral care. ${ }^{91}$ But the rule in torts is that landowners are not required to anticipate and take precautions against the wrongful acts or torts (including negligence) of others who have not been invited onto the land, and the Supreme Court has so held in a case involving trains and farmers. ${ }^{92}$ From the point of view of the law and economics of bilateral care, based as it is on two freestanding activities on an equal footing, this degree of absolutism in entitlements is deeply puzzling. ${ }^{93}$ By contrast, on theories that take information costs seriously, the landowner and the railroad are treated in a more modular fashion, and the interface is simple: the railroad must simply keep its sparks out or face liability. ${ }^{94}$ Perhaps not coincidentally, the information cost theory and a natural rights account of this rule are again quite congruent. ${ }^{95}$

${ }^{91}$ See, e.g., Cooter, supra note 82, at 5-11; Mark F. Grady, Common Law Control of Strategic Behavior: Railroad Sparks and the Farmer, 17 J. LeGAL STUD. 15, 33-41 (1988).

${ }^{92}$ See LeRoy Fibre Co. v. Chicago, Milwaukee \& St. Paul Ry., 232 U.S. 340 (1914). Wood's treatise gives a classic formulation:

It is the duty of every person or public body to prevent a nuisance, and the fact that the person injured could, but does not, prevent damages to his property therefrom is no defense either to an action at law or in equity. A party is not bound to expend a dollar, or to do any act to secure for himself the exercise or enjoyment of a legal right of which he is deprived by reason of the wrongful acts of another.

1 H.G. Wood, A Practical Treatise on the Law of Nuisances in Their Various Forms: INCLUDING REMEDIES THEREFOR AT LAW AND IN EQUITY $§ 435$ (3d ed. 1893) (citation omitted). One nineteenth-century case, Kansas Pacific Ry. v. Brady, 17 Kan. 380, 1877 WL 875 (Kan. 1877), is atypical in requiring bilateral care in a train spark case. Even this opinion recognized that the general baseline is very different: "Now it has been laid down as a general rule of law, that no one is bound to anticipate the negligence of others, or to act as though others might be negligent. But it has also been held that this rule of law has its limitations and its exceptions." 1877 WL 875, at *3. Why the departure from the baseline here? The area was extremely dry and it made sense to treat hay stacking as a special problem in general (with an analogy to gunpowder). Interestingly, even this more fine-grained approach is somewhat modular in that the court asked, "Then why should not all men be required to anticipate that average amount of negligence which must in the very nature of things be expected to transpire?" Id. (emphasis added). Average costs require less property-internal information: they are a simpler interface than one that included information about actor-specific negligence.

${ }^{93}$ See, e.g., Susan Rose-Ackerman, Dikes, Dams, and Vicious Hogs: Entitlement and Efficiency in Tort Law, 18 J. Legal StUD. 25, 35-38 (1989); see also Grady, supra note 91.

${ }^{94}$ Henry E. Smith, Property and Property Rules, 79 N.Y.U. L. ReV. 1719, 1761-62 (2004); Smith, supra note 85 , at 2098-99.

${ }^{95}$ For a natural rights approach, see Claeys, supra note 15, at 1393-94, 1413-14, 1418, 1440-42. 


\section{Proximate Cause}

Like the duty rules, proximate cause not only limits liability but also limits categories of context. As with pure economic loss (which we take up next), there is a commonly expressed concern here with "excessive" and unforeseeable liability, where "excessive" is determined by a fairly unconstrained policyoriented consideration of context. ${ }^{96}$ Here I tentatively offer an alternative account, or refinement, of the idea of "excessive liability": proximate cause sets limits on the interface between actors and the world and helps to manage the information complexity of more unconstrained liability for remote results. On the information cost account, the point is not just to limit liability but to limit categories of events so that categories of information do not bear on decision making by actors and courts. Limiting information that a duty bearer must consider, whether it comes under the duty rule or the foreseeability test of proximate cause, makes the system more modular: the interface between the actor and the world is less rich than under an unconstrained approach - whether to duty or to proximate cause.

Foreseeability is a little vague, and the element of judgment involved cannot wholly be eliminated, but within the foreseeability test the "harm-withinthe-risk" test is sometimes used to sharpen the analysis. Thus, handing a loaded gun to a child is negligent, but if it is not heavier or sharper than other objects normally given to four-year olds, then injury from his dropping it on his playmate's foot is not a harm within the risk (which is from being shot). ${ }^{97}$ Or take

\footnotetext{
${ }^{96}$ JOHN C.P. GOLDBERG \& BENJAMIN C. ZIPURSKY, THE OXFORD INTRODUCTIONS TO U.S. LAW: TORTS 109 (2010) ([A]s with the Palsgraf rule of relationality, it is worth taking a step back to consider what is being accomplished by negligence law's proximate cause requirement. The standard answer given by contemporary courts and commentators is that proximate cause prevents the imposition of 'excessive' liability."). Since the Realist Era the notion of excessive liability and the need to limit it through proximate cause have been regarded as a direct application of policy factors:

"Proximate cause" - in itself an unfortunate term - is merely the limitation which the courts have placed upon the actor's responsibility for the consequences of the actor's conduct. In a philosophical sense, the consequences of an act go forward to eternity, and the causes of an event go back to the dawn of human events, and beyond. But any attempt to impose responsibility upon such a basis would result in infinite liability for all wrongful acts, and would "set society on edge and fill the courts with endless litigation." As a practical matter, legal responsibility must be limited to those causes which are so closely connected with the result and of such significance that the law is justified in imposing liability. Some boundary must be set to liability for the consequences of any act, upon the basis of some social idea of justice or policy.

W. Page Keeton et Al., Prosser And Keeton On Torts $\S 41$, at $264\left(5^{\text {th }}\right.$ ed. 1984) [henceforth, Prosser AND KEETON ](footnote omitted) (quoting North v. Johnson, 59 N.W. 1012, 1012 (Minn. 1894).

${ }^{97}$ GOLDBERG \& ZIPURSKY, supra note 96, at 104.
} 
the famous case of Berry v. The Borough of Sugar Notch, ${ }^{98}$ in which a speeding trolley was hit by a falling tree. The trolley's presence under the tree would not have happened but for the speeding, but speeding, while it may be negligent for many purposes (in crashes with pedestrians or other vehicles) did not increase the risk of that type of harm. So there is no proximate cause as a matter of law. In our terms, the system of interactions is nearly decomposable in the sense that speeding has a limited set of interactions with the rest of the world, and to the extent that a whole classes of interactions are not important - one can vary the variable without affecting those aspects of the world - it makes sense to rule them out of the interface wholesale.

A closer look at where foreseeability does and does not cut off liability under proximate cause as a matter of law, suggests a concern for information costs and the employment of modularity to manage them. Unforeseeability comes in four categories: (i) unforeseeable plaintiffs, (ii) unforeseeable types of harm, (iii) unforeseeable extent of harm, and (iv) unforeseeable manner of harm. ${ }^{99}$ Consistent with managing complexity through modularity, unforeseeability tends to work more in an on/off fashion, rather than as a cut-off along a continuum, when unforeseeability can be based on types. Thus, (i) unforeseeable types of plaintiffs and (ii) unforeseeable types of harm are more subject to limits based on proximate cause's foreseeability requirement than are (iii) unforeseeable extent of harm and (iv) unforeseeable manner of harm. I offer it only as a tentative hypothesis, but it may be that persons and types of harms define psychologically distinct situation-types, whereas the extent and manner of harm are variables within basic situation types. ${ }^{100}$ If so, more complexity cost is saved by ruling out situation types, than imposing a cut-off within a situation type that still must be attended to.

The first category, of unforeseeable plaintiffs, is illustrated by Palsgraf, and can be thought of as raising an issue of duty or proximate cause. Is there any difference? Duty lends itself to resolution as a matter of law, and proximate cause is framed as more factual and harder to take away from a jury. ${ }^{101}$ One might also hypothesize that the relevant situation-types are defined by the identity of the possible plaintiff, and proximate cause limits the situations that are relevant.

Does ruling out scenarios based on plaintiff-type pose a problem for an economic analysis? At first one might think so, because there seems to be no reason sounding in efficiency for eliminating liability to some of these plaintiffs,

\footnotetext{
9843 A. 240 (Pa. 1899).

${ }^{99}$ KenNeth S. ABRAHAM, THE FormS AND FunCtions OF TORT LAW 132-40 (3d ed. 2007).

${ }^{100}$ On situation types, see JON BARWISE, THE SituATION IN LOGIC 79-92 (1987); JON BARWISE \& John Perry, Situations and Attitudes (1983); Keith Devlin, LogiC And Information 4951 (1991).

${ }^{101}$ GOLDBERG \& ZIPURSKY, supra note 96, at 106.
} 
and it is not clear that they are literally unforeseeable. ${ }^{102}$ But, again, an economic analysis based on information costs and one based on duty sounding in corrective justice or civil recourse turn out to dovetail more than one might expect. "Substantive standing" cases, which have been taken as a refutation of law and economics, ${ }^{103}$ potentially receive an explanation: modularity requires a simple interface and limiting the class of plaintiffs is one way to do that.

The second category, of unforeseeable types of harm, also leads to invocation of proximate cause to cut off liability. In the famous Wagon Mound case, the Privy Council held that a defendant who had negligently flushed oil into Sydney Harbor, which had caught fire and burned the plaintiff's dock, would not be liable because the type of harm was unforeseeable (clogging the dock would have been foreseeable). ${ }^{104}$ Despite some broad language in the opinion, later courts have taken it to rule out only unforeseeable harm, not unforeseeable extent of harm (the eggshell plaintiff), ${ }^{105}$ to which we turn next. As with plaintiff-type, I offer the hypothesis that harm-type defines situation-type leading to large information cost savings when it is excluded from the negligence inquiry. But this may be hard to test, both because there is no hard and fast distinction between type and extent of harm, and because most courts in the United States do not push the limit on unforeseeable type of harm as far as the court in Wagon Mound. ${ }^{106}$

The third category, of unforeseeable extent of harm, is not easy to distinguish from unforeseeable type of harm, but to the extent that it is, courts are less inclined to curtail liability. ${ }^{107}$ Sometimes the retention of liability here goes under the heading of the "eggshell skull" plaintiff or the principle that the defendant takes the plaintiff as he finds him. ${ }^{108}$ So if the victim of a car accident who had a weak heart dies of a heart attack brought on by the crash where a person with a normal heart would have survived, a negligent defendant is liable for the death. ${ }^{109}$ Again, although there is some ambiguity as to whether an

\footnotetext{
${ }^{102}$ See, e.g., Benjamin C. Zipursky, Rights, Wrongs, and Recourse in the Law of Torts, 51 VAND. L. REV. 1, 47 (1998).

${ }^{103} I d$. ("Because the law and economics model relies upon foreseeability in this way, it is illequipped to explain the substantive standing requirement. The domain of cases decided under the substantive standing rule includes many in which the harm to the plaintiff is foreseeable.").

${ }^{104}$ Overseas Tankship (U.K.), Ltd. V. Morts Dock \& Eng'g Co., [1961] All E.R. 404 (P.C.) (Wagon Mound I). Note the similarity to the Palsgraf duty rule based on forseeability. GOLDBERG \& ZIPURSKY, supra note 96, at 104.

${ }^{105}$ ABRAHAM, supra note 99 , at 139.

${ }^{106} \mathrm{Id}$.

${ }^{107} \mathrm{Id}$. at 135.

${ }^{108}$ See Prosser AND KeETON supra note $\S 43$, at 292 ( $5^{\text {th }}$ ed. 1984).

${ }^{109}$ See Benn v. Thomas, 512 N.W.2d 537 (Iowa 1994); see also Primm v. U.S. Fid. \& Guar. Ins. Corp., 922 S.W.2d 319, 321 (Ark. 1996) ("[A] tortfeasor must accept a plaintiff as he finds him and may not escape or reduce damages by highlighting the injured party's susceptibility to injury.”).Vosberg v. Putney, 47 N.W. 99 (Wis. 1890).
} 
instance of harm might be unforeseeable as to extent or as to type, ${ }^{110}$ there is some tendency for unforeseeability to go along with the characterization as "type" rather than "extent." It would be worthwhile to test this distinction psychologically.

The fourth and final category, of unforeseeable manner of harm, also tends not to be subject to a limit on liability under proximate cause. Thus, if a person is injured after an accident by being hit after walking down the road and while warning other traffic away, a jury is entitled to find the plaintiff who caused the accident tying up traffic liable for the injury. ${ }^{111}$ As with the extent of harm, it is possible that an actor or a court is already expending cognitive resources on contemplating a scenario and adding a further extent of harm or a different manner of harm does not entail large marginal cost - compared to considering fresh scenarios with different plaintiffs or entirely different types of harm.

The foreseeability test built into the proximate cause requirement displays some modularity in that tort law makes some effort to rule out types of unforeseeable risks from the actor's conduct, namely those that are not the type that makes us regard the conduct in question as careless. More generally, proximate cause analysis is more categorical than an economic analysis minus information costs would point to.

\section{Pure Economic Loss}

The need for modular structures in tort law helps explain and justify the otherwise puzzling rule in tort law denying recovery for pure economic loss - where there is injury to economic interests but no injury to person or property. ${ }^{112}$ Most law and economics explanations focus on the possibility of endless liability -

${ }^{110}$ The Second Restatement states the traditional eggshell plaintiff rule as follows:

The negligent actor is subject to liability for harm to another although a physical condition of the other which is neither known nor should be known to the actor makes the injury greater than that which the actor as a reasonable man should have foreseen as a probable result of his conduct.

RestatemEnt (SECOND) OF TORTS $§ 461$ (1965). Interestingly the Third Restatement also mentions "type" as well as "extent" of harm.

When an actor's tortious conduct causes harm to a person that, because of a preexisting physical or mental condition or other characteristics of the person, is of a greater magnitude or different type than might reasonably be expected, the actor is nevertheless subject to liability for all such harm to the person.

Restatement (ThiRd) OF TORTS: LIAB. Physical Harm $\S 31$ (2005).

${ }^{111}$ Marshall v. Nugent, 222 F.2d $604\left(1^{\text {st }}\right.$ Cir. 1955).

112 See, e.g., Robins Dry Dock \& Repair Co. v. Flint, 275 U.S. 303 (1927) (Holmes, J.); Ultramares Corp. v. Touche, 174 N.E. 441 (N.Y. 1931) (Cardozo, J.); Restatement Third Economic Torts and Related Wrongs, Council Draft No. 1, Part II, Ch. 3, *8. 
indeterminate and open-ended liability. ${ }^{113}$ But it remains puzzling why pure economic loss should not be recoverable. Theories abound. ${ }^{114}$ One suggestion is that another economic actor will benefit from the displaced business, as where an auto accident blocks customers from frequenting one business, say an ice cream store, which they desert for a close substitute nearby. ${ }^{115}$ Again, we would have to know vast amounts of contextual information to know whether this is a loss to society or not - including not just the location of ice cream stores but the consumer surplus from frequenting the blocked one, other substitutes for ice cream, the utility of shifting ice cream consumption to different times of the day or days of the week, etc., etc. ${ }^{116}$ Perhaps in keeping with how much potentially relevant contextual information there might be and the apparent arbitrariness of the dividing line from a narrowly economic point of view (apart from the architectural benefits of modularity in terms of information costs), courts have of late made a number of exceptions to the economic loss rule and it is harder than it once was to say what exactly the rule is. ${ }^{117}$

Worse still, the most puzzling aspects of the economic loss rule are in some sense the most robust. The most famous applications of the rule involve denying recovery to someone who is in only what might be termed "indirect privity" with the tortfeasor, and I will concentrate on situations in which the plaintiff is someone who is in a contractual relationship with the owner of damaged property. ${ }^{118}$ Consider the classic case of Robins Dry Dock \& Repair Co. v. Flint, ${ }^{119}$ in which a ship was destroyed though the defendant's negligence. The U.S. Supreme Court per Justice Holmes held that only the ship owner can sue for the loss of the ship, measured by market damages, but someone who rented the

${ }^{113}$ See Fleming James, Jr., Limitations on Liability for Economic Loss Caused by Negligence: A Pragmatic Appraisal, 25 VAND. L. REV. 43 (1972).

${ }^{114}$ See, e.g., William Bishop, Economic Loss in Tort, 2 OXFord J. LEgAL STUD. 1 (1982); Victor P. Goldberg, Recovery for Economic Loss Following the Exxon Valdez Oil Spill, 23 J. Legal Stud. 1 (1994); Richard A. Posner, Common Law Economic Torts: An Economic and Legal Analysis, 48 ARIZ. L. REV. 735 (2006); Robert L. Rabin, Tort Recovery for Negligently Inflicted Economic Loss: A Reassessment, 37 STAN. L. ReV. 1513 (1985).

${ }^{115}$ Bishop, supra note 114, at 5-13.

${ }^{116} I d$.

${ }^{117}$ Anthony Niblett, Richard A. Posner, \& Andrei Shleifer, The Evolution of a Legal Rule, 39 J. LEGAL STUD. 325 (2010).

${ }^{118}$ I leave for another day the question whether the information cost explanation helps justify applications of the economic loss rule to situations in which no contract is involved. For example, if a truck driver slams into a bridge and causes physical damage to the bridge requiring it to be close for three weeks, and the closure hurts a business dependent on bridge traffic, does it make sense to direct truck drivers only to avoid physical damage and not to consider more far-flung effects? I thank John Goldberg for raising this point.

119275 U.S. 303 (1927) (Holmes, J.); see also Peter Benson, The Problem with Pure Economic Loss, 60 S.C. L. REV. 823, 838-50 (2009). 
ship cannot sue for the loss of his contract rights. The renter must sue the owner, who in turn can sue the tortfeasor, following the line of "indirect privity." The property is treated as a module with the contract internal to it, whose interface with the outside world is through the in rem rights the owner has in the ship. The "internal" information about the allocation of the risks under the contract and the possible adoption of even greater risk by the owner (for example if the owner warranted the ship for a particular purpose) is normally of no relevance to the outside world, and it is made irrelevant to potential tortfeasors by the economic loss doctrine. Duty bearers are just responsible for the standard information about ships they might damage. Thus, the more traditional and doctrinal view of the economic loss rule - that one can only recover from the tortfeasor if one has an in rem property right that has been violated ${ }^{120}$ - receives an alternative explanation in terms of information costs: the economic loss rule preserves the modularity of the system by making the contract mostly internal to a property module with a simple interface to the outside world. In this way, we can be more specific about what excess or "unforeseeable" liability would be.

This view of the economic loss rule also points to which applications are the most marginal. In the case of the car accident blocking the ice cream store, it is harder to see why there should not be liability. If the question is whether an in rem right was violated, the case is much closer. Blocking a public street is a classic public nuisance, ${ }^{121}$ and the person whose land is next to the blockage is particularly injured and so under the modern approach to public nuisance would be able to sue. ${ }^{122}$ In a similar fashion, tortfeasors who cause a toxic spill that causes the evacuation of a large area likewise are creating a nuisance. ${ }^{123}$ Limiting liability here may or may not be a good idea, but it is less compelling from an information cost point of view than disallowing liability in "indirect privity" cases like Robins.

Thus, under the economic loss rule, recovery is only allowed to one who holds an in rem property right, whether these are rights of ownership or rights against nuisances. Contractual and other relations between the owner and others are walled off and treated separately. This makes sense on information-cost grounds. In rem property rights are designed to be broadcast to the world and have a simplicity and standardization that contract rights do not have. In other words, property rights are meant for an audience of impersonally interacting

\footnotetext{
${ }^{120}$ Benson, supra note 119.

${ }^{121}$ William L. Prosser, Private Action for Public Nuisance, 52 VA. L. REV. 997, 998 (1966).

122 Bishop, supra note 114 , at 26-27. For a discussion of standing and the traditional limits on public nuisance, see Thomas W. Merrill, Is Public Nuisance a Tort?,_ J. TORT L.

${ }^{123}$ See People Express Airlines, Inc. v. Consolidated Rail Corp., 495 A.2d 107 (N.J. 1985). The connection to nuisance and other torts is noted in GOLDBERG \& ZIPURSKY, supra note 96, at 125; see also Bishop, supra note 114, at 26.
} 
parties like potential tortfeasors. How rights are internally carved up are idiosyncrasies that are deal-internal and are not allowed to impose information costs on third parties. ${ }^{124}$

This architectural approach to the economic loss rule is hard to evaluate empirically. To some extent we have to ask whether a system in which the property, tort, and contract subsystems have defined spheres and interact in simple ways has the indirect effect of making the incentives facing potential tortfeasors simple and the baseline from which people contract clear. Sometimes only suggestive evidence will be available. But the foregoing does suggest that the traditional approach and the economic approach need not be all that far apart.

\section{The Development of Tort Law}

As reflected in the malicious competition cases, tort law used to implement a modular structure through the writ system. ${ }^{125}$ The mysterious distinction between trespass and trespass on the case can be regarded as a method of managing complexity through modularity. ${ }^{126}$ Trespass was reserved for injuries that were direct. By contrast, trespass on the case involved injuries that were indirect. By and large, we can say that if an injury could be found to be a trespass, the liability would be more automatic, but the law was more selective in what counted as trespass on the case. Trespass on the case involved a more elaborate interface between actors and so required more selectivity in order to maintain modularity.

This modular structure of a first cut with more automatic liability and more refined, though more selective, interfaces is reflected in the modern-day descendants of the trespass writs. ${ }^{127}$ The distinction between trespass to land and nuisance (the latter deriving from trespass on the case rather than the older writ of nuisance) implements such a modular structure.

Older tort law is often criticized as being too formal, but before turning to more recent law, it is worthwhile to consider a possible functional justification for some degree of formalism in tort law. Much of the doctrine discussed above

\footnotetext{
${ }^{124}$ In a more generalized setting, trusts and other entity property often allow in personam "internal" parties to allocate rights in resources among themselves in a way that the law keep from being relevant in rem to outsiders. See, e.g., Thomas W. Merrill \& Henry E. SMith, PROPERTY: PRINCIPLES AND POLICIES 684-829 (2007); Merrill \& Smith, supra note 2, at 843-49.

${ }^{125}$ Implementing the substance of tort law though procedure may have bee unattractive and led to the decline of the writ system. See G. Edward White, The Intellectual Origins of Torts in America, 86 YALE L.J. 671, 678-83 (1977).

${ }^{126}$ On trespass and trespass on the case, see CECIL H.S. FifoOt, History AND SOURCES OF THE COMMON LAW 66-73 (1949).

${ }^{127}$ Frederic William Maitland, The Forms of Action at Common Law 2 (1936) ("The forms of action we have buried, but they still rule us from their graves.”).
} 
under negligence, proximate cause, and the economic loss rule, render tort law less responsive to context, and so more formal.

Many of these aspects of older and more formal tort law broke down over the course of the twentieth century. One possible reason is that they imposed too much modularity, particularly with rising stakes. As in property where increasing externalities or scarcity (reflected in rising resource values) can lead to more exclusion or more governance depending on which is least cost, ${ }^{128}$ tort law might simply have been responding to the need for building in relations, like that between producer and injury victim, into the interfaces between actors. This is certainly a theoretical possibility. It is also possible that because modularity in torts is not as natural as it is in property, which relies on a thing for mediating between actors, it was easier to overlook the architectural benefits of modularity and formalism in torts. This essay is not the place to determine the optimal type and degree of formalism in tort law, but one cautionary note is in order. In discussions of whether to broaden or loosen notions of negligence, proximate cause, and economic loss, or to reformulate them in economic terms, account must be taken of the complexity-managing benefits of formalism implemented through modular structures.

\section{THE MORALITY OF TORT LAW}

The information cost theory dovetails with deontological theories of torts for the simple reason that legal norms that draw on widespread moral norms are easier to communicate. Especially where the legal norm is otherwise potentially costly, this advantage can be important.

In this, tort law is like property, which likewise reaps information cost advantages from relying on moral norms like that against stealing. ${ }^{129}$ Property also relies on reciprocal forbearance in its governance rules - think nuisance which also gains content from natural rights and local norms. ${ }^{130}$ Nuisance is a

\footnotetext{
${ }^{128}$ Smith, supra note 40 . In other words, we can refine the Demsetzian prediction that rising resource values and greater externalities will lead to "more property rights," Harold Demsetz, Toward a Theory of Property Rights, 57 Am. Econ. ReV. 347, 350 (1967) (Papers \& Proc.), in terms of the various exclusion and governance strategies for implementing property.

${ }^{129}$ See Merrill \& Smith, supra note 12. Some aspects of this reliance on morality for information cost reasons relate closely to how mechanisms serve the "rule of law." See, e.g., LON L. FULLER, The Morality of LAw (1964); Lisa M. Austin, Property and the Rule of Law (Draft, University of Toronto, April 2011); Gillian K. Hadfield \& Barry R. Weingast, What is Law? A Coordination Account of the Characteristics of Legal Order, J. LEGAL ANALYSIS (forthcoming) (Stanford Law and Economics Olin Working Paper No. 404; USC CLEO Research Paper No. C10-17; USC Law Legal Studies Paper No. 10-20), available at SSRN: http://ssrn.com/abstract=1707083.

${ }^{130}$ See supra notes 13-15 and accompanying text; see also Robert C. Ellickson, Alternatives to Zoning: Covenants, Nuisance Rules, and Fines as Land Use Controls, 40 U. CHI. L. REV. 681, 728-33 (1973) (arguing that nuisance should be based in part on local norms).
} 
tort, and torts more generally share the feature of lowering information costs through reliance on extralegal moral norms.

But nuisance is not a typical tort, and it remains to ask whether everyday morality helps reduce information cost in torts in other ways. Nuisance is a property tort and to some extent does benefit from the simplicity of a defined thing. ${ }^{131}$ It is also less in rem than trespass and many torts like assault because it involves neighboring landowners. Although a large nuisance might involve many landowners, land does not typically move around and so the classes of right holders and duty bearers are rather stable and somewhat limited. Because it does not have fixed neighbors we do not have a tort of "nuisance to chattels."

For torts in general, the duties enshrined in the law have been explained in moral terms. ${ }^{132}$ This is usually seen as a challenge to law and economics. But I would argue that in a close parallel to property, ${ }^{133}$ the heavy reliance on moral duties in torts makes the law of torts simpler and more robust than if it rested directly on cost-benefit analysis, as we saw in the previous Part. Information cost theory points to a more traditional structure of torts, which as in the case of property not coincidentally looks a lot like the common denominator of Kantian, corrective justice and civil recourse theories of torts. It is even compatible with a high-level utilitarianism that is attentive to modular architecture, as opposed the rule-by-rule is-it-efficient school of law and economics. ${ }^{134}$

If we add a concern with information costs to the law and economics of torts, then the economic explanations and justifications of tort law look less different from those based on corrective justice and civil recourse. ${ }^{135}$ Law and

\footnotetext{
${ }^{131}$ Smith, supra note 54, at 990-1007.

132 See the sources cited in notes 13-15 supra.

${ }^{133}$ Merrill \& Smith, supra note 12.

${ }^{134}$ I do not rule out that for information cost reasons, the message of tort law might diverge from that of the best moral theory, because it is easier to communicate. Thus, the reasons explored by John Goldberg and Benjamin Zipursky for identifying negligence as a form of wrongdoing sound in everyday concerns and messages. John C.P. Goldberg \& Benjamin C. Zipursky, Tort Law and Moral Luck, 92 CoRnell L. REV. 1123, 1154-57 (2007). Tort law defines the duty in terms of success rather than best efforts, because "[a] system of norms that uses success verbs to define required conduct and failure verbs to define impermissible conduct sends a stronger message about how society expects its members to behave." Id. at 1158. They contrast their view with that of John Gardner, which they take to be based on a duty to try. Id. at $1157 \mathrm{n} .115$, citing John Gardner, Obligations and Outcomes in the Law of Torts, in RELATING TO RESPONSIBILITY: ESSAYS IN HONOUR OF TONY HONORÉ ON HIS 80TH BIRTHDAY 111, 120. Even less formal and more informationally demanding are theories that emphasize the role of standards in order to induce moral deliberation, with the expectation that people will converge on the same correct result. See, e.g. Seana Valentine Shiffrin, Inducing Moral Deliberation: On the Occasional Virtues of Fog, 123 HARV. L. REV. 1214 (2010) (arguing that the vagueness of standards is beneficial in terms of inducing moral deliberation on the part of duty bearers).

${ }^{135}$ As with information costs, widening a theory to include incidental costs and benefits of tort law has the potential to bring corrective justice and law-and-economics accounts of tort law somewhat
} 
economics can give an account of the bilateral structure of tort law and gives information cost reasons for moral rights and duties to be woven into tort law. This is not to say that information costs exhaust the reasons for tort law to have this structure, ${ }^{136}$ nor does it mean that law and economics is no different from noneconomic theories.

The information cost approach does point to the inadequacy of rule-byrule low-level utilitarian explanations of tort law. But nothing argued here can distinguish a more architectural utilitarian account of tort law from those based on deontological theories, corrective justice, or civil recourse. What this suggests is that much of tort law can be explained - uniquely or alternatively, it is hard to say - by paying attention to how the structure of tort law reflects the practicalities of implementing it. An architecture that reflects information costs is important to tort law and is closely related to its grounding in everyday morality. What interests ground torts and what the nature of rights is remain open questions on the account offered here. ${ }^{137}$ Instead, information costs can be pushed further than heretofore as an explanation of the structure of torts and help explain how the delineation of tort law dovetails with morality, in a fashion parallel to property law. Tort is like property but in an architectural sense, based on information flow.

\section{CONCLUSION}

The information cost theory solves the puzzle of in rem rights that appear not to be standardized like those of property. Torts, like property, employs modular structures to manage complexity. Unlike property with its heavy reliance on the simplicity and information hiding effect of things as modules, tort law rules out wide swathes of contextual information through some of its most traditional aspects, including its bilateral structure, duty rules, proximate cause, and the like. Those aspects of tort law that have been most emphasized in corrective justice, civil recourse, and natural rights theories of tort law can also be seen as formal in the sense of relatively context-insensitive and as promoting modularity in tort law. Because these aspects of torts are grounded in everyday morality, they make the

closer together. See Scott Hershovitz, Harry Potter and the Trouble with Tort Theory, 63 STAN. L. REV. 67 (2010).

${ }^{136}$ See Merrill \& Smith, supra note 12 , at 1852, 1867, 1894-95.

${ }^{137} \mathrm{Cf}$. COLEMAN, supra note 16, at $36 \mathrm{n} .20$ (allowing for the possibility that a corrective justice theory of tort law leaves open the question of justification at the level of grand political theory); Mark A. Geistfeld, Efficiency, Fairness, and the Economic Analysis of Tort Law, in THEORETICAL FOUNDATIONS OF LAW AND ECONOMICS 234, 252 (Mark D. White ed., 2009) (“Just as economic analysis must be guided by a normative principle in the initial specification of legal entitlements and the ultimate specification of the social welfare function, the normative principle also depends on economic analysis at the stage of implementation . . . The two modes of analysis are complements and not substitutes.”). 
in rem duties tort law simpler and easier to enforce, in a parallel fashion to property. The information cost theory helps explain the relation of tort and property and brings the economic and noneconomic approaches to tort law closer together at the level of delineation of rights. The information cost theory suggests that the real differences between tort theories lie at a more foundational level. 